\title{
Dietary supplement use
}

Citation for published version (APA):

Pajor, E. M. (2019). Dietary supplement use: reasons, decisions, and health communication . [Doctoral Thesis, Maastricht University]. Datawyse / Universitaire Pers Maastricht.

https://doi.org/10.26481/dis.20190911ep

Document status and date:

Published: 01/01/2019

DOI:

10.26481/dis.20190911ep

Document Version:

Publisher's PDF, also known as Version of record

\section{Please check the document version of this publication:}

- A submitted manuscript is the version of the article upon submission and before peer-review. There can be important differences between the submitted version and the official published version of record.

People interested in the research are advised to contact the author for the final version of the publication, or visit the DOI to the publisher's website.

- The final author version and the galley proof are versions of the publication after peer review.

- The final published version features the final layout of the paper including the volume, issue and page numbers.

Link to publication

\footnotetext{
General rights rights.

- You may freely distribute the URL identifying the publication in the public portal. please follow below link for the End User Agreement:

www.umlib.nl/taverne-license

Take down policy

If you believe that this document breaches copyright please contact us at:

repository@maastrichtuniversity.nl

providing details and we will investigate your claim.
}

Copyright and moral rights for the publications made accessible in the public portal are retained by the authors and/or other copyright owners and it is a condition of accessing publications that users recognise and abide by the legal requirements associated with these

- Users may download and print one copy of any publication from the public portal for the purpose of private study or research.

- You may not further distribute the material or use it for any profit-making activity or commercial gain

If the publication is distributed under the terms of Article $25 \mathrm{fa}$ of the Dutch Copyright Act, indicated by the "Taverne" license above, 
Propositions accompanying the PhD thesis

\section{Dietary supplement use}

Reasons, decisions, and health communication

Emília Margit Pajor, 11 September 2019

1. Dietary supplement users and non-users differ in attitudes towards supplement use and trust in health professionals and food quality, but hold similar levels of knowledge, risk perception, and misconceptions. | This thesis

2. Health regulatory focus (promotion) is an important determinant of dietary supplement use and needs to be taken into account in models to understand dietary supplement use. | This thesis

3. Consumers' decisions in favour or against dietary supplement use are not optimal in terms of informed decision-making. | This thesis

4. The use of interactive features in online health communication about dietary supplements does not improve message recall. | This thesis

5. Results that are derived both from qualitative and quantitative research are more vigorous than results derived from only one type of research.

6. Testing possible moderators and mediators of information processing mechanisms yields important insights into the effectiveness of health communication.

7. In modern societies, there is a trend towards the commercialization of health which widens the debate from the classic approach to regulate industries that produce ill health. | Kickbusch \& Payne, 2003

8. In order to make communication about dietary supplements more optimal, risk-benefit profiles of the most widely used dietary supplements should be known. 